DOI https://doi.org/10.30525/978-9934-26-073-5-2-57

\title{
SOCIOCULTURAL CONTENT WITHIN THE MODERN CULTURE OF MASS MEDIA
}

\author{
Kashchuk M. H. \\ Candidate of Pedagogical Sciences, \\ Associate Professor at the Department of Foreign Languages \\ and Culture of Professional Speech \\ Lviv State University of Internal Affairs \\ Lypchenko T. S. \\ Teacher at the Department of Foreign Languages \\ and Culture of Professional Speech \\ Lviv State University of Internal Affairs \\ Lviv, Ukraine
}

The information space becomes not just a kind of social life, but its both creative and driving force. In the famous thesis of Marshall McLuhan, who proposed to study the development of modern culture through the prism of the mass media functioning in society, the medium is also a message («the medium is the message») [1, p. 304].

In the newsroom and analytical journalism, everything has fallen into place: communication technologies have reached such a level of influence that completely materialistic media have "swallowed» the spiritual substance of messages and taken over their functions. That is why the media have become a monopoly in the field of messaging.

Understanding culture, the dynamics of its development and practical functioning is complicated by ignoring the factor of information phenomena, which are unviable outside the activity of communication processes. The phenomenon of communication (in any of its stratifications - from mass to social) will be defective without taking into account the phenomenon of culture, and in modern culture, the media are seen as a factor in the information and communication system. Therefore, it is extremely useful to trace the interaction of three social and scientific phenomena: culture, communication, mass media.

Information culture, inherent in the mass media, is often associated with media culture - a much broader and more powerful phenomenon of communication, which, according to many scholars, is a «transplant of ideas.» If we consider that communication is a rather vague phenomenon, and culture 
has no clear definite boundaries, then social structures that are exposed to the massive influence of information culture factors are to be considered from a sociological point of view.

Modern practice of functioning of the Ukrainian phenomenon of the information cultural phenomenon proves social differentiation of the culture itself. It is well known that during the years of Soviet rule in Ukraine, attempts were made to set a single unified culture, which proved the failure of the very idea of such culture, as well as the idea of creating a monolithic social organism. Historically stable society has a very complex and detailed social structure and culture.

Hence, the most important task of cultural policy, which is to promote the processes of social differentiation and hierarchy of culture, greater specialization of its individual strata in accordance with the needs of different segments of the population. At the same time, it is very important to support these social subcultures in a state of «open systems» with blurred boundaries, capable of free exchange of socially relevant forms and innovations. This is an open way to understand the phenomenon of informational cultural phenomenon in the media, the identification of journalistic creativity as a mass communication receptive activity.

The formation of the latest system of social communications is taking place in the context of accelerating Ukraine's global integration into the world community, increasing the influence of the communication factor on the processes of preserving the integrity of national statehood and restoring the spiritual priorities of society. In this socio-cultural situation, the level of content civilization in social communications depends on the quality of the functional system of social communications.

The modern world is experiencing many global problems and crises. Today's civilization opens up a wide range of opportunities for man, which can be used due to correct, thoughtful, independent decisions and actions. Modern man in a situation of constant risk expects different communication, different socio-culture, non-traditional thinking and actions, which are provided by models of social communications. Successful development of the state and a decent life in it depend on the independence, impartiality, freedom of thought of every citizen. That is why in the functioning of social communications, the process of forming a value attitude to various phenomena of reality is important, as well as the hierarchy of values of the individual, which determine his attitude to the world and behavior in society.

Content in social communications is a complex phenomenon, the formation and functioning of which is influenced by individual social institutions and groups of society. An important role in this process is played 
by the system of social communications, which in the national context should create conditions in which all the positive values of society, problems, ways to solve them would become the property of the audience.

In view of this, the task is to develop such a holistic organization of the social and communication space, which would create conditions for filling all its representatives with adequate and correct content. That is why one of the main factors in providing the audience with content of this kind is the need for adequacy of social and communication content and the maturity of the audience to which this content is intended.

The introduction of content in social communications is based on the following aspects:

- first, self-cognition and awareness of one's feelings and traits;

- secondly, the formation of "spiritual intelligence», community as the basis of the Ukrainian national character;

- third, the correlation of oneself with the demands of society, profession, faith, family.

The innovative method of functional improvement of social communications is dominated by the selection of tools and techniques in which the following features can be distinguished: the focus on the formation of adequate perception of reality; the formation of a kind of "core of personality» [2]; the state of being based on personal life experience; appeal to the whole person, his mind, will, feelings, heart and soul; focusing on the diversity of ways and forms of human life.

Everyone is, in essence, a carrier of positive (light-bearing, creative) energy, or, conversely, dark, destructive, which harmonizes or has a destructive effect on the environment.

At the turn of the XX - XXI centuries many researchers in various fields of knowledge (communicators, historians, philosophers, sociologists, political scientists, culturologists), trying to predict the further development of society, study the processes of sociocultural transformation, which means a complex, emotional transformation of society as a sociocultural system. Erasing the boundaries between the «mass» and the «elite» has become a sign of the cultural paradigm of the information society, focused on many ideas and a compromise of aesthetic positions. Communication technologies are becoming a kind of tool for informational, political and spiritual expansion, a means to create new content based on social myths, which greatly hinder the development of the creative personality of the audience, helping to develop virtual ideas and desires far from reality.

«Socioculture is a complex heterogeneous system that includes elements of various subject and social nature (material and technical objects, means of 
labor and communication, material and spiritual products, services, ideological, artistic values, patterns and norms, relations between people), which are united by human activity «[3, p. 123].

The aggravation of global problems of today, the internationalization of social life and production dictate the need to assimilate the universal values of culture. Increased attention to the implementation of these values is inspired by the task of ensuring the orientation of youth education on global issues of awareness of the priority of universal values of the cultural picture of the world, spirituality, personality culture and planetary thinking.

That is why modern communicativeness is acutely faced with the question of the need for radical reforms in social communications - such reforms that would be aimed at the comprehensive improvement of the content of social communications.

An important role in solving this problem belongs to the organization of mass media, which are designed to ensure the development of each media, creating such conditions that the content would remain at the level of audience adequacy. The driving force of human development is the need for continuous improvement. In the conditions of formation of modern social communications the way to a democratic, civilized society is caused not so much by economic and political priorities of their activity, as by the general level of development of both journalists, and audience.

\section{References:}

1. Лотман Ю. М. Система с одним языком (Культура и взрыв) / Лотман Ю. М. Семиосфера. Петербург: «Искусство-СПБ», 2000. 458 с.

2. Козлов Н. Простая правильная жизнь / Н. Козлов. М.: Астрель, 2009.

3. Новікова Т. Л. До проблеми формування соціокультурних цінностей майбутніх офіцерів-прикордонників у процесі вивчення гуманітарних дисциплін / Т. Л. Новікова. Збірник наукових праць Хмельницького інституту соціальних технологій Університету «Україна», 2011. № 4. С. 123-126.

4. Опалюк О. М., Сербалюк Ю. В. Культура спілкування. Психологічні основи професійного спілкування. Навч.-метод. посібник / Камянець-Подільський держ. ун-т / О.М. Опалюк, Ю.В. Сербалюк. Кам.-Подільський, 2004. С. 95-97. 